\title{
Hypothalamic-pituitary-gonadotropic function in girls with premature thelarche
}

\author{
A M PASQUiNo, F PICCOLO, A SCALAMANDRE, M MALVASO, R ORTOLANI, AND \\ B BOSCHERINI
}

1st Paediatric Clinic, University of Rome, Italy

SUMMARY Hypothalamic-pituitary-gonadotropic activity was investigated in 9 girls with premature thelarche, and compared with that in 9 healthy girls and 6 girls with true precocious puberty. The gonadotropin stimulation test with luteinising hormone-releasing hormone was used. Girls with premature thelarche showed luteinising hormone response resembling that of normal girls, and follicle-stimulating hormone (FSH) response quite similar to that of girls with precocious puberty. This suggests that in premature thelarche there is a partial activation of the diencephalichypophyseal-gonadal axis, which affects FSH only. Premature thelarche therefore, should be considered as one of the disorders due to altered sensitivity of the hypothalamic receptors which regulate sexual maturation.

The premature development of the breast without any other clinical signs of sexual maturation termed premature thelarche by Wilkins ${ }^{1}$ is not uncommon in girls under 8 years of age, with the highest incidence between 1 and 4 years. ${ }^{1-3}$ Premature thelarche is not a progressive condition ${ }^{1-2} 4$ and therefore, from a clinical point of view, it generally is not a serious problem.

The pathogenesis of premature thelarche is still controversial. According to some $\mathrm{e}^{2-7}$ the premature development of the breast is due to an abnormal sensitivity of the target tissue to the small physiological amounts of oestrogens present in early life. Others ${ }^{6-9}$ suggest that premature thelarche can be ascribed to an autonomous overproduction of oestrogens by those ovarian follicles which undergo cystic transformation and luteinisation between the first and fourth years of age: in some girls such hormonal spurts are sufficient to induce a partial development of the mammary gland, and also a certain degree of maturation of the vaginal epithelium.

More recently, on the basis of studies of hypothalamic-pituitary-gonadotropic function, it was suggested that patients with premature thelarche might show increased gonadotropin secretion, which in turn would cause increased oestrogen production. ${ }^{410-11}$ Such findings however, have not been confirmed by others. ${ }^{712}$

We report an investigation of hypothalamic- pituitary-gonadotropic function in a group of 9 girls with premature thelarche, and compare our findings with 9 healthy girls and 6 girls with true precocious puberty.

\section{Materials and methods}

Nine girls, aged between 1.5 and $6 \cdot 2$ years, with premature thelarche, were studied; their clinical data are given in Table 1. Bone age was evaluated by the TW2 method. ${ }^{13}$ The degree of breast development was assessed according to the stages given by Marshall and Tanner. ${ }^{14}$ The annual growth rate was calculated by the standards of Tanner and Whitehouse. ${ }^{15}$ Height was evaluated on the basis of Tonelli's centiles. ${ }^{16}$

Vaginal smears were stained by the Papanicolaou method, after fixing in ether-95\% alcohol (1:1), and were interpreted according to Kaufman and Leeds. ${ }^{17}$ Maturation index (MI) represented the percentage of counted cells divided into a parabasal, intermediate, or superficial group. An MI of 100/0/0 indicated that vaginal epithelium showed no oestrogenic stimulation since it was made exclusively of parabasal cells, whereas if the index moved to the right $(0 / 0 / 100)$ - that is, an increased percentage of the superficial layers-increased oestrogenic stimulation was indicated.

The gonadotropin stimulation test was performed in the fasting state at 9 a.m., by a rapid intravenous 
injection of $50 \mu \mathrm{g}$ synthetic luteinising hormonereleasing hormone (LH-RH). Blood samples were collected at time 0 and then at 10,20,30,60, and 90 minutes. Separated plasma was stored at $-20^{\circ} \mathrm{C}$.

Follicle-stimulating hormone (FSH) and luteinising hormone $(\mathrm{LH})$ were assayed in duplicate by radioimmunoassay 18-19 using anti-LH and antiFSH sera, absorbed with human chorionic gonadotropin (Biodata). Concentrations are reported in $\mathrm{mIU} / \mathrm{ml}$ of the 2nd international reference preparation-human menopausal gonadotropin (IRP-HMG), so that $1 \mathrm{mIU} \mathrm{LH}$ corresponds to 5 ng LER 907.

The gonadotropin response to LH-RH was expressed in terms of the highest concentrations (FSH and LH maximum peak) and also of maximum increment. The statistical analysis was carried out on the mean \pm SEM values obtained in patients with premature thelarche compared with: (1) a group of 9 girls, aged between 1.5 and 7 years, who had been admitted to the endocrinology department on the suspicion of endocrine disorder. All had had vaginal bleeding, proved in one case to be due to a foreign body and in the remainder to vaginitis, and (2) a group of 6 untreated girls with true idiopathic precocious puberty aged between 1.2 and 6.8 years. All 15 girls submitted to the stimulation test with their parents' consent.

Significance of difference between the mean values of the three groups was calculated by the Student's $t$ test: $\mathbf{P}<0.01$ was chosen as the lowest limit of significance.

\section{Results}

Clinical observation was carried out during a period of 1 to $2 \frac{1}{2}$ years (Table 1). The heights and height velocities of the premature thelarche girls were normal. Bone age agreed with chronological age within $\pm 1 \mathrm{SD}$. The degree of breast development ranged between Tanner's B2 and B3 stages. The first signs of breast development appeared between the first week of life and age 6 years. A regression to B1 stage was observed in 3 girls and to B2 in the others.

In all girls the vaginal smears showed clear signs of oestrogenisation, slight in 2 and more pronounced in 7.

The gonadotropin response to $\mathrm{LH}-\mathrm{RH}$ was different in the three groups (Table 2). Both maximum peak and increment $(\triangle)$ of FSH differed from the values seen in girls with true precocious puberty (Figs 1 and 3). However, maximum peak and increment of LH in girls with premature thelarche were not significantly higher than the values in healthy girls $(P>0.01)$, and were significantly lower $(P<0 \cdot 001)$ than the values in girls with true precocious puberty (Figs 2 and 3).

Table 1 Premature thelarche: clinical data of 9 cases

\begin{tabular}{|c|c|c|c|c|c|c|c|c|c|c|}
\hline \multirow[t]{2}{*}{ Case } & \multirow[t]{2}{*}{ Age (years) } & \multirow[t]{2}{*}{ Bone age } & \multirow{2}{*}{$\begin{array}{l}\text { Height } \\
\text { (centile) }\end{array}$} & \multirow{2}{*}{$\begin{array}{l}\text { Observation } \\
\text { period (years) }\end{array}$} & \multirow{2}{*}{$\begin{array}{l}\text { Height } \\
\text { velocity } \\
(S D)\end{array}$} & \multirow{2}{*}{$\begin{array}{l}\text { Age at } \\
\text { onset } \\
\text { (years) }\end{array}$} & \multicolumn{2}{|l|}{ Breast stage } & \multicolumn{2}{|c|}{ Vaginal smear } \\
\hline & & & & & & & $\begin{array}{l}\text { First } \\
\text { observation }\end{array}$ & Subsequent & $\begin{array}{l}\text { Oestrogenic } \\
\text { stimulation }\end{array}$ & $M I$ \\
\hline 1 & $3 \cdot 9$ & $3 \cdot 8$ & 10 & $2 \cdot 5$ & $+1 \cdot 0$ & $3 \cdot 9$ & $\mathrm{~B}_{2}$ & $\mathrm{~B}_{1}$ & Slight & $50 / 40 / 10$ \\
\hline 2 & $2 \cdot 1$ & $2 \cdot 3$ & 90 & $1 \cdot 5$ & $+1 \cdot 0$ & $2 \cdot 0$ & $\mathrm{~B}_{2}$ & $\mathrm{~B}_{1}$ & Fair & $50 / 25 / 25$ \\
\hline 3 & $5 \cdot 5$ & $5 \cdot 3$ & 3 & $2 \cdot 5$ & -1.0 & Birth & $\mathrm{B}_{3}$ & $\mathbf{B}_{1}$ & Strong & $25 / 40 / 35$ \\
\hline 4 & $2 \cdot 7$ & $3 \cdot 0$ & 50 & $1 \cdot 5$ & -0.6 & Birth & $\mathbf{B}_{3}$ & $\mathrm{~B}_{2}$ & Fair & $50 / 25 / 25$ \\
\hline 5 & $1 \cdot 5$ & $1 \cdot 5$ & 50 & $2 \cdot 5$ & +0.3 & $1 \cdot 5$ & $\mathbf{B}_{3}$ & $\mathbf{B}_{1}$ & Slight & $50 / 40 / 10$ \\
\hline 6 & $5 \cdot 3$ & $6 \cdot 0$ & 25 & $1 \cdot 5$ & +0.2 & Birth & $\mathrm{B}_{2}$ & $\mathbf{B}_{1}$ & Fair & $50 / 25 / 25$ \\
\hline 7 & $4 \cdot 3$ & $4 \cdot 8$ & 25 & 1.0 & +0.2 & $2 \cdot 0$ & $\mathrm{~B}_{2}^{2}$ & $\mathrm{~B}_{2}$ & Fair & $50 / 25 / 25$ \\
\hline 8 & $6 \cdot 2$ & $7 \cdot 3$ & 50 & 1.0 & -0.5 & $6 \cdot 0$ & $\mathrm{~B}_{2}^{2}$ & $\mathrm{~B}_{2}^{2}$ & Fair & $50 / 25 / 25$ \\
\hline 9 & $2 \cdot 0$ & $2 \cdot 7$ & 75 & $1 \cdot 5$ & +0.8 & 0.3 & $\mathrm{~B}_{3}$ & $\mathrm{~B}_{2}^{2}$ & Fair & $50 / 25 / 25$ \\
\hline
\end{tabular}

MI = Maturation index (see text).

Table 2 Baseline plasma values and responses to $L H-R H$ stimulation of FSH and LH (means $\pm S E$ ) in premature thelarche, precocious puberty, and normal subjects

\begin{tabular}{|c|c|c|c|c|c|c|}
\hline Group & $\begin{array}{l}\text { Basal FSH } \\
(\mathrm{mlU} / \mathrm{ml})\end{array}$ & $\begin{array}{l}\text { Maximum } \\
F S H(m I U / m l)\end{array}$ & $\begin{array}{l}\text { Maximum } \\
\text { FSH increment } \\
(\mathrm{mIU} / \mathrm{ml})\end{array}$ & $\begin{array}{l}\text { Basal LH } \\
(m I U / m l)\end{array}$ & $\begin{array}{l}\text { Maximum } \\
L H(m l U / m l)\end{array}$ & $\begin{array}{l}\text { Maximum } \\
\text { LH increment } \\
(\mathrm{m} I \mathrm{U} / \mathrm{ml})\end{array}$ \\
\hline $\begin{array}{l}\text { Premature thelarche }(n=9) \\
\text { Precocious puberty }(n=6) \\
\text { Normal subjects }(n=9) \\
\text { Significance of differences, P }\end{array}$ & $\begin{array}{l}4 \cdot 1 \pm 0 \cdot 6 \\
6 \cdot 2 \pm 1 \cdot 2 \\
2 \cdot 6 \pm 0 \cdot 3\end{array}$ & $\begin{array}{l}27 \cdot 1 \pm 3 \cdot 4 \\
26 \cdot 0 \pm 2 \cdot 4 \\
14 \cdot 4 \pm 1 \cdot 7\end{array}$ & $\begin{array}{l}22 \cdot 9 \pm 2 \cdot 9 \\
20 \cdot 5 \pm 1 \cdot 8 \\
11 \cdot 8 \pm 1 \cdot 8\end{array}$ & $\begin{array}{l}1 \cdot 5 \pm 0 \cdot 1 \\
2 \cdot 6 \pm 0 \cdot 7 \\
1 \cdot 5 \pm 0 \cdot 1\end{array}$ & $\begin{array}{l}9 \cdot 5 \pm 1 \cdot 1 \\
36 \cdot 6 \pm 7 \cdot 6 \\
6 \cdot 5 \pm 0 \cdot 8\end{array}$ & $\begin{array}{l}8 \cdot 0 \pm 1 \cdot 1 \\
34 \cdot 0 \pm 7 \cdot 4 \\
5 \cdot 0 \pm 0 \cdot 7\end{array}$ \\
\hline $\begin{array}{l}\text { Premature thelarche v. precocious puberty } \\
\text { Precocious puberty v. normal } \\
\text { Premature thelarche v. normal }\end{array}$ & $\begin{array}{l}\text { NS } \\
<0 \cdot 005 \\
\text { NS }\end{array}$ & $\begin{aligned} & \text { NS } \\
< & 0.001 \\
< & 0.0025\end{aligned}$ & $\begin{aligned} & \text { NS } \\
&<0.0025 \\
&<0.0025\end{aligned}$ & $\begin{array}{l}\text { NS } \\
\text { NS } \\
\text { NS }\end{array}$ & $\begin{array}{l}<0.001 \\
<0.001 \\
\text { NS }\end{array}$ & $\begin{array}{l}<0.001 \\
<0.001 \\
\text { NS }\end{array}$ \\
\hline
\end{tabular}

NS $=$ not significant $(>0.01)$ 


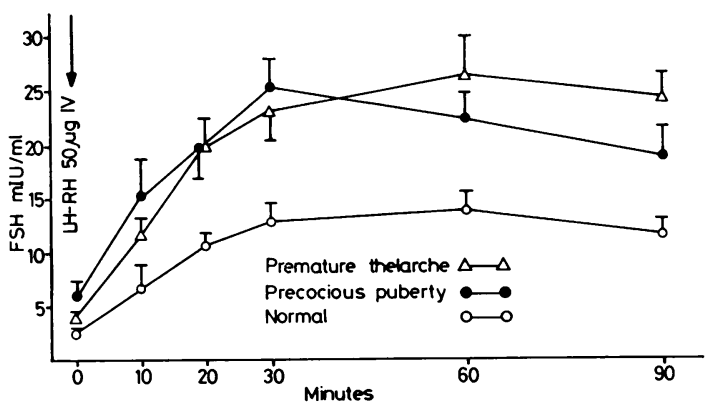

Fig. 1 FSH after $\mathrm{LH}$-RH stimulation in premature thelarche.

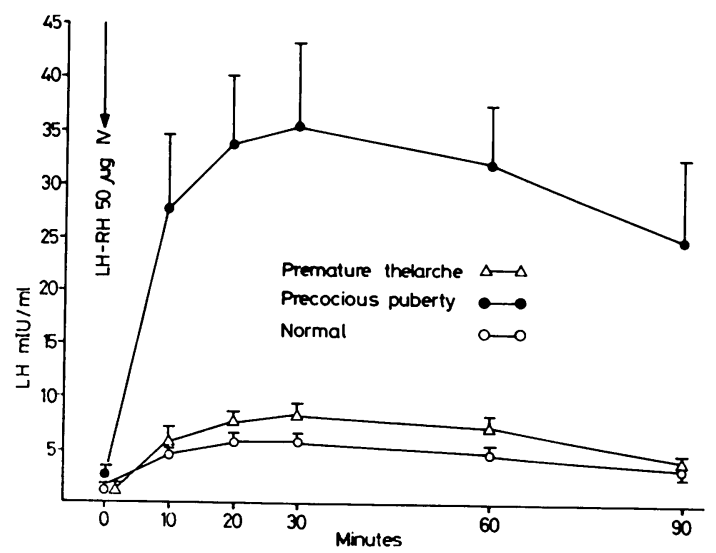

Fig. $2 L H$ after $\mathrm{LH}-\mathrm{RH}$ stimulation in premature thelarche.

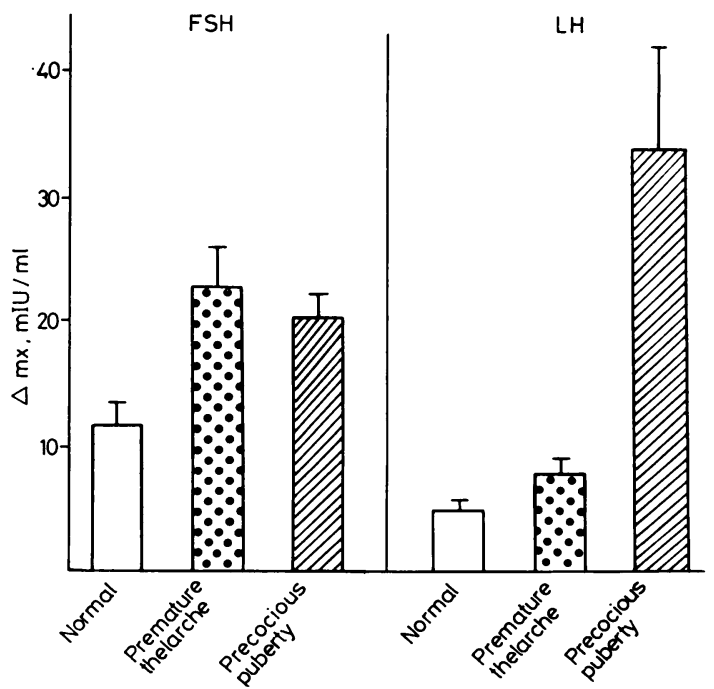

Fig. 3 FSH and LH maximum increment in normal subjects,

\section{Discussion}

Clinical findings in our patients (Table 2) are in agreement with those already published regarding the time of onset of precocious breast development, reversibility of premature thelarche, and absence of acceleration in both height and bone age. ${ }^{1-4} 7$

All patients showed signs of oestrogenisation of the vaginal epithelium, in agreement with other reports ${ }^{\text {7-8 20-22 }}$ but not in agreement with all. 1-2 $^{2} 917$

As far as hypothalamic-pituitary-gonadotropic function was concerned after LH-RH stimulation, we found increased plasma FSH as is present in girls with precocious puberty; LH levels however, were not significantly different from values seen in normal girls of comparable ages (Table 2 and Figs 1 , 2 , and 3). The unusual behaviour of gonadotropins seems to indicate that in premature thelarche a partial hypothalamic-pituitary-gonadotropic activation occurs which affects FSH only.

High plasma FSH levels have been observed both during the first year of life $\mathrm{e}^{22}$ and in the early phase of puberty, when FSH increase precedes that of LH by about one year. ${ }^{22-23}$ Since patients with premature thelarche show not only breast development but also, according to our findings, constant oestrogenisation of the vaginal epithelium and increased FSH production, it seems probable that in premature thelarche and in early puberty a similar chain of events occurs.

Premature thelarche might therefore, be included among the conditions that depend on altered sensitivity to steroids of the hypothalamic receptors controlling sexual maturation. If this is the case, a disturbance of receptors regulating FSH secretion would cause the early occurrence of thelarcheusually a transient phenomenon-whereas a disturbance affecting the receptors of both gonadotropins would account for the fully developed picture of true precocious puberty, which is generally persistent and only exceptionally has been described as a transient condition. ${ }^{24}$

From a practical point of view, the present study emphasises the usefulness of the gonadotropin simulation test with LH-RH in girls with premature breast development, as such a test distinguishes between premature thelarche and true precocious puberty.

We are grateful to Dr G Mancuso and Mr G Davi for the laboratory investigations.

\section{References}

1 Wilkins L. The diagnosis and treatment of endocrine disorders in childhood and adolescence, third edition, Springfield: Thomas, 1965: 206, 
2 Altchek A. Premature thelarche. Pediatr Clin North Am 1972; 19: 543-5.

3 Bierich J R. Sexual precocity. Clin Endocrinol Metab $1975 ; 4:$ 107-42.

4 Job J C, Guilhaume B, Chaussain J L, Garnier P E. Le developpement prématuré isolé des seins chez les fillettes. Resultats de l'epreuve a la LH-RH. Arch Fr Pediatr 1975; 32: 39-48.

5 Dresch C, Arnal M, Prader A. Étude de 22 cas de développement prématuré isolé des seins ou 'premature thelarche'. Helv Paediatr Acta 1960; 15: 585-93.

6 Jenner M R, Kelch R P, Kaplan S L, Grumbach M M. Hormonal changes in puberty. IV. Plasma estradiol, LH, and FSH in prepubertal children, pubertal females, and in precocious puberty, premature thelarche, hypogonadism, and in a child with a feminizing ovarian tumor. J Clin Endocrinol Metab 1972; 34: 521-30.

7 De Sanctis C, Bisbocci D, Frajria R, Boccuzzi G, Lala R, Angeli A. La risposta gonadotropinica all 'LH-RH e la risposta prolattinemica al TRH nel telarca prematuro. Riv Ital Pediatria 1977; 3: 185-93.

8 Collett-Solberg P R, Grumbach M M. A simplified procedure for evaluating estrogenic effects and the sex chromatin pattern in exfoliated cells in urine: studies in premature thelarche and adolescent gynecomastia. J Pediatr 1965 ; 66: 883-90.

- Capraro V J, Bayenet-Rivera N P, Aceto T, Mac Gillivray M. Premature thelarche: a review. Obstet Gynecol Surv 1971; 26: 2-7.

10 Kenny F M, Midgley A R, Jr, Jaffe R B, Garces L Y, Vazquez A, Taylor F H. Radioimmunoassayable serum LH and FSH in girls with sexual precocity, premature thelarche, and adrenarche. J Clin Endocrinol Metab 1969; 29: 1272-5.

11 Reiter E O, Kaplan S L, Conte F A, Grumbach M M. Responsivity of pituitary gonadotropins to luteinizing hormone-releasing factor in idiopathic precocious puberty, precocious thelarche, precocious adrenarche, and in patients treated with medroxyprogesterone acetate. Pediatr Res 1975; 9: 111-6.

12 Caufriez A, Wolter R, Govaerts M, L'Hermito M, Robyn C. Gonadotropins and prolactin pituitary reserve in premature thelarche. J Pediatr 1977; 91: 751-3.

13 Tanner J M, Whitehouse R H, Marshall W A, Healy M J R, Goldstein H. Assessment of skeletal maturity and prediction of adult height (TW2 method). London: Academic Press, 1975.

14 Marshall W A, Tanner J M. Variations in pattern of pubertal changes in girls. Arch Dis Child 1969; 44: 291-303.

15 Tanner J M, Whitehouse $\mathbf{R}$ H. Clinical longitudinal standards for height, weight, height velocity, weight velocity, and stages of puberty. Arch Dis Child 1976; 51 : 170-9.

16 Tonelli E. Studio statistico sulla variabilità della statura e del peso in soggetti Emiliani di età tra 1 e 14 anni. G Igiene Med Prev 1963; 4: 3-17.

17 Kaufman R H, Leeds L J. Cervical and vaginal cytology in the child and adolescent. Pediatr Clin North Am 1972; 19: 547-57.

18 Midgley A R, Jr. Radioimmunoassay: a method for human chorionic gonadotropin and human luteinzing hormone. Endocrinology 1966; 79: 10-8.

19 Midgley A R. Radioimmunoassay for human folliclestimulating hormone. J Clin Endocrinol Metab 1967; 27: 295-9.

20 Preeyasombat C, Kenny F M. Urocytogram in normal children and various abnormal conditions. Pediatrics $1966 ; 38$ : 436-43.

21 August G P. Diagnosis of disorders of sexual maturation. Pediatr Clin North Am 1971; 18: 313-33.

22 Job J C, Canlorbe P. Evaluation de la fonction hypophyso-gonadique dans les pubertés féminines normales et pathologiques. Proceedings of the Third International Symposium on Pediatric and Adolescent Gynecology, Lausanne, 25-27 March 1976: 93.

23 Gupta D. Hormone im Kindesalter. Stuttgart: Schattauer Verlag, 1980: 166.

24 Bourguignon J P, Ernould Ch, Gaspard U, Franchimont P. L'exploration de la secretion des gonadotrophines au cours de la pubertè normale, precoce et retardée. Proceedings of the Third International Symposium on Pediatric and Adolescent Gynecology, Lausanne, 25-27 March 1976: 126.

Correspondence to Dr A M Pasquino, Via Deruta 19, 00181 Rome, Italy.

Received 11 October 1979 